\title{
PERKARA IZIN POLIGAMI DI PENGADILAN AGAMA BENGKALIS (Analisis Terhadap Putusan Hakim Nomor: 0307/Pdt.G/2017/PA.Bkls)
}

\author{
Khairil Anwar1, Sri Ikamulia² \\ ${ }^{1}$ Sekolah Tinggi Agama Islam Negeri Bengkalis, \\ e-mail: khairilaljufri@gmail.com) \\ ${ }^{2}$ Sekolah Tinggi Agama Islam Negeri Bengkalis, \\ e-mail: ikamulia91@yahoo.com)
}

\begin{abstract}
This study aims at determining the basic considerations of the Panel Judges in Bengkalis Religious Court in granting Polygamy Permit to case Number: 0307/Pdt.G / 2017 /PA.Bkls. Additionally, this study also to find out the normative juridical review of this Judge's Decision. The results of this study indicate that this polygamy permit application is only eccomplish the cumulative requirements, but does not eccomplish the alternative conditions. Therefore honestly this application should have been rejected. However, the Bengkalis Religious Court in this case granted the application by using the Contra Legem principle in order to fill the legal vacuum on the basis of the mudhorot or harmfulness which contained in this case. This is excatly in accordance with the fiqhiyah method: "Iza Ta'arodho Mafsadatani Ru'iya" Adhohuma Dhororon Birtikabi Akhofuba "which means that if there are two cases that are equally harmful or degrading, then it must be safeguarded by a greater degree of harmfulness, by working on a lighter Mudharat or the danger.
\end{abstract}

Kata kunci: Izin poligami, Putusan Hakim, contra legem.

\section{PENDAHULUAN}

$\mathcal{P}$ erkawinan merupakan sebuah aqad yang ditetapkan oleh syariat, sehingga dengan aqad tersebut seorang laki-laki memiliki hak serta dibolehkan untuk bersenang-senang dengan seorang perempuan. (Al-Zuhaili, 2010) Tujuan utama dari sebuah perkawinan dalam Islam adalah untuk membentuk rumah tangga yang sakinah mawaddah dan rahmah. Hal ini sebagai mana firman Allah SWT:

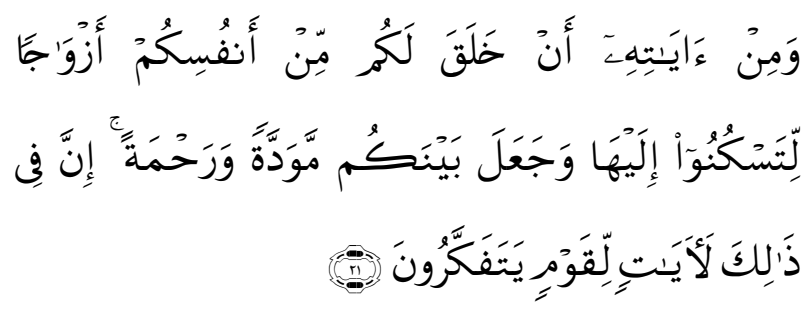

"Dan di antara tanda-tanda kekuasaan-Nya ialah Dia menciptakan untukmu isteri-isteri dari jenismu sendiri, supaya kamu cenderung dan merasa tenteram kepadanya, dan dijadikan-Nya diantaramu rasa kasih dan sayang. Sesungguhnya pada yang demikian itu benar-benar terdapat tanda-tanda bagi kaum yang berfikir". (Q.S. ar-Ruum [30]: 21)

Pada prinsipnya perkawinan dalam Islam adalah monogami. Monogami adalah sistem yang hanya memperbolehkan seorang laki-laki mempunyai satu istri pada jangka waktu tertentu (Bahasa, 2005). Meskipun demikian, asas monogami ini tidak bersifat mutlak, Islam memperbolehkan seorang laki-laki untuk menikahi lebih dari seorang wanita dengan syarat ia 
mampu berlaku adil kepada mereka baik dalam urusan pangan, pakaian, tempat tinggal dan lain sebagainya. Hal ini sebagai mana firman Allah swt dalam surat an-Nisaa ayat 3 yang berbunyi:
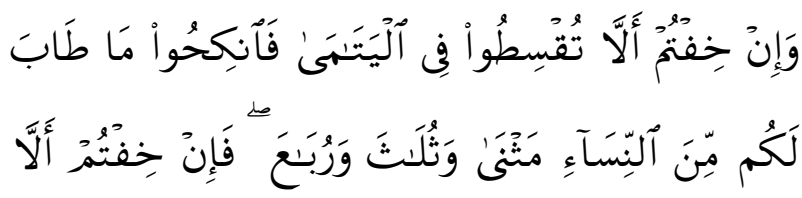

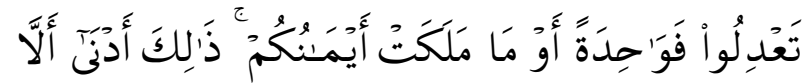

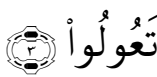

"Dan jika kamu takut tidak akan dapat Berlaku adil terhadap (hak-hak) perempuan yang yatim (bilamana kamu mengawininya), Maka kawinilah wanita-wanita (lain) yang kamu senangi: dua, tiga atau empat. kemudian jika kamu takut tidak akan dapat Berlaku adil Maka (kawinilah) seorang saja, atau budak-budak yang kamu miliki. yang demikian itu adalah lebih dekat kepada tidak berbuat aniaya". (Q.S. an-Nisaa [4]:3).

Adapun secara yuridis formil, Pada dasarnya undang-undang perkawinan juga menganut asas monogami. Hal ini sebagaimana diatur dalam Pasal 3 Ayat (1) Undang-undang Nomor 1 Tahun 1974 yang berbunyi: "Pada asasnya seorang pria hanya boleh memiliki isteri. Seorang wanita hanya boleh memiliki seorang suami". Akan tetapi undang-undang tersebut memberikan kemungkinan kepada suami untuk melakukan poligami dengan mengharuskan meminta izin kepada pengadilan, hal ini sebagai mana diatur dalam ayat 2 yang berbunyi:" pengadilan dapat memberikan izin kepada seorang suami untuk beristri lebih dari seorang apabila dikehendaki oleh pihak-pihak yang bersangkutan".
Perkawinan poligami itu sah menurut undang-undang yang berlaku maka dalam pengajuannya harus memenuhi sekurang-kurang salah satu syarat alternatif dan ketiga syarat komulatif (M. Lia Armadhani, 2016) Syarat alternatif sebagai mana diatur dalam pasal 4 ayat (2) diantaranya adalah: a. Istri tidak dapat menjalankan kewajibannya sebagai istri, b. Istri mendapat cacat badan atau penyakit yang tidak dapat disembuhkan, c. Istri tidak dapat melahirkan keturunan. Adapun syarat komulatif sebagai mana diatur dalam pasal 5 ayat (1) yang berbunyi: a. Adanya persetujuan dari isteri, b. Adanya izin dari pengadilan agama, c. Adanya kepastian bahwa suami mampu untuk menjamin keperluan hidup isteri-isteri dan anak-anak mereka.

Meskipun perkara izin poligami sudah ada ketentuan dan peraturannya baik di dalam syariah Islam maupun Perundang-undangan di Indonesia, namun sering kali dalam prakteknya izin poligami tidak sesuai dengan hukum dan undang-undang yang berlaku. Kebanyakan dari mereka melakukan poligami hanya karena pemenuhan nafsu belaka, sehingga terkadang mereka terkesan mengada-adakan alasan demi merealisasikan keinginannya. Seperti kasus yang terjadi di Pengadilan Agama Bengkalis dengan nomor perkara 0307/Pdt. G/2017/PA. Bkls. Dalam kasus ini pihak suami mengajukan permohonan poligami dengan alasan bahwa sebelum Pemohon melangsungkan pernikahan dengan Termohon, Pemohon juga telah menjalin hubungan kasih dengan calon istri Pemohon. Kemudian antara keduanya sudah berhubungan layaknya suami istri, dan sekarang calon istri Pemohon 
tersebut dalam keadaan hamil, sehingga ia harus mempertanggung jawabkan atas perbuatannya tersebut. Sedangkan pernikahannya dengan isteri pertama baru berlangsung selama lebih kurang 1 bulan yang lalu.

Berdasarkan kenyataan di atas, maka dapat dipastikan bahwa tidak diketemukan sebab-sebab yang menjadi alasan dibolehkannya perizinan poligami sebagaimana diatur dalam UU Nomor 1 Tahun 1974 tentang Perkawinan Pasal 4 ayat (2) maupun dalam Kompilasi Hukum Islam (KHI) Pasal 57. Oleh karena itu, tulisan ini mencoba mengkaji secara mendalam apa dasar Majlis Hakim dalam mengabulkan permohonan perkara izin poligami dengan Nomor perkara: 0307/Pdt.G/2017/PA.Bkls? Bagaimana analisis Yuridis Normatif dan Hukum Islam Terhadap Putusan Hakim tersebut?

\section{METODE PENELITIAN}

Jenis penelitian ini menggunakan penelitian hukum empiris atau non doktrinal atau yuridis normatif dimana berdasarkan fakta atau kenyataan di lapangan yaitu dilakukan dengan cara meneliti bahan-bahan pustaka dan data sekunder yang terdiri dari bahan hukum primer, bahan hukum sekunder dan bahan hukum tersier.

Sifat Penelitian ini adalah deskriptif analisis, yaitu penelitian yang dapat diartikan sebagai prosedur atau cara memecahkan masalah penelitian dengan memaparkan keadaan objek yang diselidiki (seseorang, lembaga, masyarakat dan lain sebagianya) berdasarkan fakta- fakta aktual pada saat sekarang (Hadari Nanawi, 1983) Pada penelitian ini pendekatan yang digunakan yaitu dengan melakukan penelusuran terhadap bahanbahan hukum yang digunakan sebagai legal decision atau dasar untuk membuat keputusan hukum.

Adapun sumber data pada penelitian ini dapat dibagi menjadi dua; primer dan sekunder. Data primer yaitu data yang didapatkan langsung dari subjek penelitian, adapun data primer terkait tentang penelitian ini didapatkan dari Putusan Hakim tentang izin poligami di Pengadilan Agama Bengkalis. Sedangkan data sekunder yaitu data yang didapatkan tidak langsung dari sumber subjek penelitian melainkan didapatkan dari pihak lain.

Selanjutnya teknik pengumpulan data yang digunakan untuk memperoleh data primer dalam penelitian ini adalah dengan cara field research yaitu merupakan teknik pengumpulan data dengan cara penelitian langsung kepada objek yang diteliti. Sedangkan teknik pengumpulan data yang digunakan dalam pengumpulan data sekunder yaitu dengan cara library reseach yaitu dengan membaca dan mempelajari perundang-undangan, buku-buku literatur, dan dokumen resmi yang terkait dengan penelitian. Kemudian metode analisis data yang digunakan setelah data dikumpulkan adalah dengan metode Content Analysis.

\section{PEMBAHASAN}

\section{Pengertian Poligami}

Secara etimologis kata poligami, berasal dari bahasa Yunani yang terdiri dari dua kata yaitu polus yang berarti banyak, sedangkan gamos berarti perkawinan. Bila pengertian kata ini 
digabungkan, maka poligami akan berarti suatu perkawinan yang banyak atau lebih dari seorang (Chotban, 2017). Sedangkan pengertian poligami menurut Kamus Besar Bahasa Indonesia mempunyai makna "sistem perkawinan yang salah satu pihak memiliki atau mengawini beberapa lawan jenisnya dalam waktu yang bersamaan" (Bahasa, 2005) Adapun dalam kamus Ilmiah Populer, poligami adalah perkawinan antara seorang dengan dua orang atau lebih, namun cenderung diartikan perkawinan satu orang suami dengan dua istri atau lebih. (Pius A. Partanto dan M. Dahlan al-Barry, 1994) Sedangkan dalam Fiqh Islam poligami biasa disebut dengan istilah "Ta'addud azZujat" yang diartikan sebagai kebolehan seorang suami untuk menikahi lebih dari seorang istri dengan jumlah maksimal adalah empat orang dengan syarat ia mampu berlaku adil dan untuk menjaga sebuah kemaslahatan.

\section{Poligami Menurut Hukum Islam}

Islam memperbolehkan poligami, dasar hukum kebolehannya sebagaimana firman Allah SWT dalam Surat an-Nisa' ayat 3 yang bebunyi:

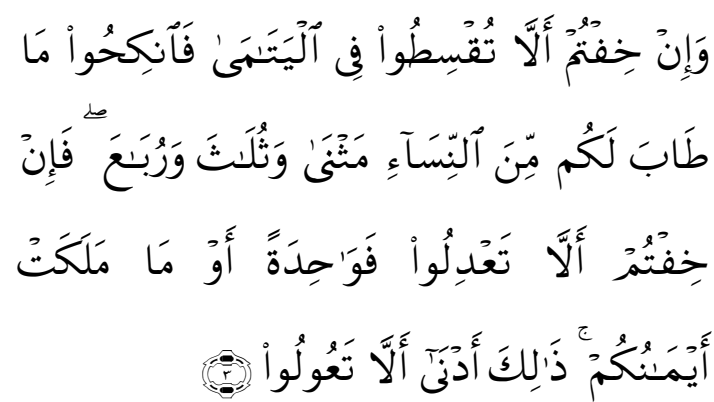

"Dan jika kamu takut tidak akan dapat Berlaku adil terhadap hak-hak perempuan yang yatim bilamana kamu mengawininya, Maka kawinilah wanita-wanita lain yang kamu senangi : dua, tiga atau empat. kemudian jika kamu takut tidak akan dapat Berlaku adil, Maka kawinilah seorang saja, atau budak-budak yang kamu miliki. yang demikian itu adalah lebih dekat kepada tidak berbuat aniaya". (Q.S. an-Nisa [4]: 3)

Meskipun Islam memperbolehkan poligami tetapi kebolehan itu bukan secara mutlak. Abdu Attawwab Haikal dalam kitabnya " Ta'addud az-Zaujah fii al-Islam" menjelaskan bahwa setidaknya ada beberapa alasan darurat yang membolehkan poligami di antaranya: (Haikal, 2006)

1. Istri memiliki penyakit yang tidak dapat disembuhkan sehingga menyebabkan tidak dapat menjalankan kewajibannya sebagai istri.

2. Istri memiliki cacat yang permanen.

3. Istri mandul sehingga tidak dapat memberikan keturunan.

4. Istri menghidap penyakit yang menular sehingga tidak dapat menjalankan tugas sebagai istri.

5. Istri memiliki naluri syahwat yang rendah, sementara suami memiliki naluri syahwat yang tinggi.

\section{Poligami Menurut UU Perkawinan dan KHI}

Pada dasarnya undang-undang perkawinan menganut asas monogami. Hal ini diatur dalam Pasal 3 Ayat (1) Undang-undang Nomor 1 Tahun 1974, yang berbunyi: "Pada asasnya seorang pria hanya boleh memiliki isteri. Seorang wanita hanya boleh memiliki seorang suami". Akan tetapi Undangundang tersebut memberikan kemungkinan kepada suami untuk melakukan poligami dengan syarat meminta izin kepada pengadilan. 
Lebih lanjutnya dalam Kompilasi Hukum Islam pasal 55 dijelaskan bahwa:

1. Beristri lebih dari satu orang pada waktu yang bersamaan, terbatas hanya sampai empat istri.

2. Syarat utama beristri lebih dari seorang, suami harus mampu berlaku adil terhadap isteri-isteri dan anak-anaknya.

3. Apabila syarat utama yang disebut pada ayat (2) tidak mungkin dipenuhi, suami dilarang beristri dari seorang.

Agar pengadilan dapat mengabulkan permohonan izin poligami tersebut, pengajuan perkara harus memenuhi alasan-alasan sebagaimana yang diatur dalam Pasal 4 Undang-undang Nomor 1 Tahun 1974, yakni:

a. Istri tidak dapat menjalankan kewajibannya sebagai isteri.

b. Isteri mendapatk cacat badan atau penyakit yang tidak dapat disembuhkan.

c. Isteri tidak dapat melahirkan keturunan

Sedangkan dalam Kompilasi Hukum Islam pasal 57 dijelaskan bahwa: Pengadilan Agama hanya memberikan izin kepada seorang suami yang akan beristri lebih dari seorang apabila:

a. Istri tidak dapat menjalankan kewajibannya sebagai isteri

b. Isteri mendapatk cacat badan atau penyakit yang tidak dapat disembuhkan

c. Isteri tidak dapat melahirkan keturunan

Selanjutnya dalam pasal 58 Kompilasi Hukum Islam menyebutkan:

1) Selain syarat utama yang disebut pada pasal 55 ayat (2) maka untuk memperoleh izin Pengadilan Agama, harus pula dipenuhi syarat-syarat yang ditentukan pada pasal 5 Undang-undang Nomor 1 Tahun 1974 yaitu:

a. Adanya persetujuan isteri

b. Adanya kepastian bahwa suami mampu menjamin keperluan hidup isteri-isteri dan anak-anak mereka.

2) Tidak mengurangi ketentuan pasal 41 huruf b Peraturan Pemerintah No. 9 Tahun 1975, persetujuan isteri atau isteri-isteri dapat diberikan secara tertulis atau dengan lisan, tetapi sekalipun telah ada persetujuan tertulis, persetujuan ini dipertegas dengan persetujuan lisan isteri pada sidang Pengadilan Agama

3) Persetujuan dimaksud pada ayat (1) huruf a tidak diperlukan bagi seorang suami apabila isteri atau isteri-isterinya tidak mungkin dimintai persetujuannya dan tidak dapat menjadi pihak dalam perjanjian atau apabila tidak ada kabar dari isteri atau isteri-isterinya sekurang-kurangnya 2 tahun atau karena sebab lain yang perlu mendapat penilaian Hakim.

Seorang suami yang akan mengajukan permohonan izin poligami Kemudian syarat-syarat yang harus dipenuhi oleh menurut Undangundang Perkawinan Tahun 1974, pasal 5 (2) yaitu:

a) Adanya persetujuan dari isteri/isteri-isteri.

b) Adanya kepastian bahwa suami mampu menjamin keperluankeperluan hidup isteri-isteri dan anak-anak mereka. 
c) Adanya jaminan bahwa suami akan berlaku adil terhadap isteri-isteri dan anak-anak mereka.

\section{Duduk Perkara Putusan Nomor: 0307/Pdt.G/2017/PA.Bkls}

Bahwa Pemohon dalam surat permohonannya tertanggal 25 April 2017 yang didaftarkan di Kepaniteraan Pengadilan Agama Bengkalis, Nomor: 0307/Pdt.G/2017/PA.Bkls tanggal 4 Mei 2017, telah mengajukan permohonan izin poligami terhadap Termohon dengan dalil-dalil sebagai berikut.

Bahwa pada tanggal 09 Maret 2017 Pemohon dengan Termohon melangsungkan pernikahan yang dicatat oleh Pegawai Pencatat Nikah Kantor Urusan Agama Kecamatan Bunut Kabupaten Pelalawan, sebagaimana yang tertera dalam Buku Kutipan Akta Nikah Nomor: 42/05/III/2017, tanggal 09 Maret 2017.

Bahwa setelah pernikahan tersebut Pemohon dengan Termohon bertempat tinggal di rumah orang tua Pemohon. Bahwa sebelum melangsungkan pernikahan tersebut, status Pemohon dan Termohon adalah duda dengan memiliki dua orang anak, sedang Termohon berstatus perawan. Bahwa setelah pernikahan tersebut Pemohon dan Termohon telah hidup rukun, sebagaimana layaknya suami istri namun belum dikaruniai keturunan.

Bahwa Pemohon hendak menikah lagi (Poligami) dengan seorang perempuan berusia 38 tahun. Bahwa Pemohon mengajukan izin poligami ini, disebabkan karena sebelum Pemohon melangsungkan pernikahan dengan Termohon, Pemohon juga telah menjalin hubungan kasih dengan calon istri Pemohon. Antara Pemohon dengan calon istri Pemohon telah berhubungan layaknya suami istri, dan sekarang calon istri Pemohon tersebut sudah/dalam keadaan hamil. Bahwa akibat dari hal tersebut, maka Pemohon hendak melakukan poligami.

Bahwa Termohon menyatakan rela dan tidak keberatan apabila Pemohon menikah lagi dengan calon isteri Pemohon yang kedua tersebut, serta Termohon bersedia dimadu oleh Pemohon. Oleh karena itu Pemohon hendak menikah lagi dengan calon isteri kedua Pemohon. Karena Pemohon sangat khawatir akan membahayakan kondisi perkembangan janin/calon bayi, yang sekarang masih dalam kandungan calon isteri Pemohon apabila Pemohon tidak melakukan poligami.

Bahwa Pemohon sanggup berlaku adil dan mampu memenuhi kebutuhan hidup isteri-isteri beserta anak-anak Pemohon. Bahwa Pemohon mampu memenuhi seluruh kebutuhan hidup rumah tangga dengan anak-anak, dan 2 orang isteri dan Pemohon mempunyai penghasilan setiap bulannya sebesar Rp. 8.000.000-,

Berdasarkan uraian diatas, Pemohon memohon kepada Ketua Pengadilan Agama Bengkalis atau Majelis Hakim Pengadilan Agama Bengkalis yang memeriksa dan mengadilkan perkara tersebut, berkenan memberikan putusan hukum tentang izin poligami kepada Pemohon yang berinisial $\mathrm{R}$ dengan calon isteri kedua pemohon yang berinisial $\mathrm{Z}$.

5. Amar Putusan dan Dasar Pertimbangan Hakim 
Terhadap kasus di atas, Pengadilan Agama Bengkalis melalui putusan Nomor 0307/Pdt.G/2017/PA.Bkls pada tanggal 20 Jui 2017 telah menjatuhkan putusan yang amarnya berbunyi sebagai berikut:

1. Mengabulkan permohonan Pemohon;

2. Memberi izin kepada Pemohon berinisial $\mathrm{R}$ untuk menikah lagi (poligami) dengan calon isterinya yang berinisial Z;

3. Membebankan biaya kepada Pemohon untuk membayar biaya perkara sejumlah Rp. 1.031.000,00 (satu juta tiga puluh satu ribu rupiah);

Adapun Dasar pertimbangan hakim dalam memutuskan perkara Nomor: 0307/Pdt. G/2017/PA. Bkls diantaranya adalah sebagai berikut:

1. Menimbang, bahwa Z sebagai calon isteri kedua menyatakan bersedia menjadi isteri kedua Pemohon dengan segala konsekwensinya, dan sebagai calon isteri kedua $\mathrm{Z}$ tidak memiliki ikatan kekeluargaan yang bisa menghalanginya menikah dengan Pemohon, dan tidak pula terikat pernikahan dengan orang lain karena $\mathrm{Z}$ telah berstatus janda yang ditinggal mati suaminya pada tahun 2012 lalu, didukung pula dengan bukti P.9;

2. Menimbang, bahwa berdasarkan posita point 9 dan 10 yang dibenarkan oleh Termohon dan didukung dengan bukti P.6 dan P.7 menurut Pemohon bahwa dirinya mampu untuk memenuhi kebutuhan hidup dan sanggup berlaku adil terhadap isteri-isteri;

3. Menimbang, bahwa berdasarkan buktibukti yang ada ditambah keterangan saksi- saksi Pemohon maupun pengakuan Termohon tersebut, Majelis Hakim mendapati fakta Pemohon telah memenuhi syarat untuk melakukan poligami, baik itu syarat alternatif maupun syarat kumulatif;

4. Menimbang, bahwa keinginan Pemohon untuk melakukan poligami ternyata didukung oleh adanya kemampuan Pemohon untuk membiaya isteri-isteri dan anak yang diharapkan, kesiapan Pemohon untuk berlaku adil serta telah mendapatkan persetujuan dari Termohon, sehingga telah memenuhi persyaratan sebagaimana dimaksud dalam Pasal 5 huruf a Undang-Undang nomor 1 Tahun 1974 Jo. Pasal 41 huruf b dan c Peraturan Pemerintah Nomor 9 Tahun 1975 Jo. Pasal 58 ayat (1) Inpres Nomor 1 Tahun 1991 Tentang Kompilasi Hukum Islam;

5. Menimbang, bahwa hubungan Pemohon dengan calon isteri Pemohon sudah begitu dekat, sehingga jika keadaan tersebut dibiarkan berlarut-larut justru mudharat dan kemaksiatan yang akan menimpa mereka, oleh karena itu member izin kepada Pemohon untuk melakukan pernikahan dengan calon isterinya tersebut merupakan solusi yang maslahah bagi semua pihak dan akan menyelesaikan persoalan yang dirasakan dalam kehidupan berumahtangga.

6. Menimbang, bahwa Majelis Hakim mempedomi firman Allah dalam Q.S An-Nisa' ayat 3 yang berbunyi: 
"Dan jika kamu takut tidak akan dapat berlaku adil terhadap (hak-hak) perempuan yang yatim (bilamana kamu mengawininya), maka kawinilah wanitawanita (lain) yang kamu senangi; dua, tiga atau empat. Kemudian jika kamu takut tidak akan dapat berlaku adil, maka (kawinilah) seorang saja, atau budak-budak yang kamu miliki. Yang demikian itu adalah lebih dekat kepada tidak berbuat aniaya." (Q.S. anNisa'[3]:3)

\section{Analisis Yuridis Normatif dan Hukum Islam Terhadap Putusan Perkara}

Menurut Peneliti, alasan diajukanya izin poligami di dalam Putusan Perkara Nomor 0307/Pdt. G/2017/PA. Bkls tidak sesuai dengan undang-undang yang berlaku. Hal ini dikarenakan alasan yang diajukan pemohon adalah karena calon istri keduanya telah lebih dulu hamil. Sehingga dapat disimpulkan bahwa alasan tersebut tidak terdapat didalam syarat komulatif sebagai mana tertuang dalam undang-undang Perkawinan ataupun Kompilasi Hukum Islam. Alasan yang dimaksud sebagai mana disebutkan dalam Pasal 4 ayat (2) yaitu: (Abdurrahman, 1992)

a. Istri tidak dapat menjalankan kewajibannya sebagai istri;

b. Istri mendapat cacat badan atau penyakit yang tidak dapat disembuhkan;

c. Istri tidak dapat melahirkan.

Namun demikian Majelis Hakim dalam putusannya tetap mengabulkan permohonan Pemohon dengan pertimbangan bahwa hubungan keduanya sudah sangat jauh sehingga calon istri kedua pemohon kini sudah hamil akibat pergaulannya tersebut. Sehingga keputusan tersebut dilakukan hakim dalam rangka untuk melindungi aspek sosiologis dan psychologis calon istri kedua pemohon serta untuk mewujudkan kepastian hukum hubungan keduanya.

Tidak bisa dipungkiri bahwa hakim sebagai aplikator undangundang wajib memahami undangundang dengan jalan mencari undangundang yang berhubungan dengan perkara yang sedang diperiksa, kemudian harus dapat menilai apakah undang-undang tersebut adil, ada kemanfaatannya serta memberikan kepastian hukum, sebab tujuan hukum adalah keadilan, kemanfaatan dan kepastian hukum ( Haryono, 2019).

Kendati untuk mengabulkan putusan perkara ini, hakim pada dasarnya menggunakan asas contra legem yaitu wewenang seorang hakim utuk menyimpangi ketentuanketentuan hukum tertulis yang telah ada, yang telah usang ketinggalan zaman sehingga tidak mampu lagi memenuhi rasa keadilan masyarakat (Saleh, 1981). Sehingga keputusan Hakim tidak lagi sesuai dengan ketentuan hukum yang berlaku, karna hakim memiliki kewenangan untuk menyalahi aturan dalam memutuskan suatu perkara apabila dirasa bahwa kebaikan yang akan ditimbulkan lebih besar dari pada keburukannya.

Sehingga penulis berkeyakinan bahwa hakim telah benar menerapkan hukum dan permohonan izin poligami yang dilakukan Pemohon tepat untuk di kabulkan. Secara yuridis, undangundang membolehkan perkawinan bagi wanita hamil di luar nikah sebagaimana tertulis dalam $\mathrm{KHI}$ bab 
VIII pasal 53 ayat 1, 2 dan 3 Sebagaimana berikut:

1. Seorang wanita hamil di luar nikah bisa dikawinkan dengan pria yang menghamilinya;

2. Perkawinan dengan wanita hamil yang disebut pada ayat (1) dapat dilangsungkan tanpa menunggu lebih dahulu kelahiran anaknya;

Namun demikian meskipun secara undang - undang membolehkan adanya perkawinan bagi wanita hamil di luar nikah dengan pria yang menghamilinya, akan tetapi itu bukan berarti status anak yang dilahirkan nantinya secara keperdataan otomatis dihubungkan kepada ayahnya, melainkan kepada ibunya dan keluarga ibunya ( Sari Pusvita, 2018). Hal ini sebagaimana tertuang dalam undangundang nomor 1 tahun 1974 pasal 34 ayat 1 yang menyatakan bahwa: "anak yang dilahirkan di luar perkawinan hanya mempunyai hubungan perdata dengna ibunya dan keluarga ibunya". Hal senada juga disebutkan dalam Kompilasi Hukum Islam pasal 100 yang menyebutkan bahwa: "anak yang lahir di luar perkawinan hanya mempunyai hubungan nasab dengan ibunya dan keluarga ibunya".

Adapun Jika dari segi Hukum Islam, putusan hakim dalam perkara izin poligami pada kasus ini pada hakikatnya didasarkan pada pertimbangan - pertimbangan terhadap bahaya serta mudharat yang akan ditimbulkan akibat pemberian atau penolakan izin poligami. Diantara mudharat yang timbul jika pengadilan agama tidak mengabulkan permohonan izin pemohon adalah sebagai berikut:

1. Calon isteri Pemohon tersebut akan senantiasa dilanda keresahan hingga lambat laun akan mempengaruhi kesehatan dan perkembangan janin.

2. Untuk menutub aib yang terjadi pada diri dan keluarganya maka tidak mustahil calon isteri Pemohon akan nekad melakukan perbuatan keji seperti aborsi maupun bunuh diri (suicide).

3. Hubungan Pemohon dengan calon isteri Pemohon sudah begitu dekat, sehingga jika keadaan tersebut dibiarkan berlarut-larut justru mudharat dan kemaksiatan yang lebih besar akan menimpa mereka seperti perzinaan dan perselingkuhan.

4. Calon istri pemohon dan calon anak yang akan dilahirkan tidak memiliki kepastian hukum karena masuk dalam kategori istri siri dan anak luar nikah.

Sementara di sisi yang lain, mudharat yang muncul jika Pengadilan Agama mengabulkan permohonan izin pemohon adalah akan muncul sebuah anggapan bahwa berbuat zina meskipun dosa besar tapi bisa menjadi alasan untuk permohonan izin poligami di pengadilan agama, sehingga mereka akan menggunakan cara atau modus yang sama demi merealisasikan tujuan mereka.

Dalam kondisi seperti ini, dikarenakan kemudaharaan yang timbul jika pengadilan agama tidak mengabulkan permohonan izin pemohon adalah lebih besar dibanding dengan kemudaharatan yang timbul jika pengadilan agama mengabulkan 
permohonan izin pemohon, oleh karena itu memberi izin kepada Pemohon untuk melakukan pernikahan dengan calon isterinya tersebut merupakan solusi yang tepat dalam menyelesaikan permasalahan ini. Hal ini senada dengan Kaedah Fiqhiyah: (Djazuli, 2006)

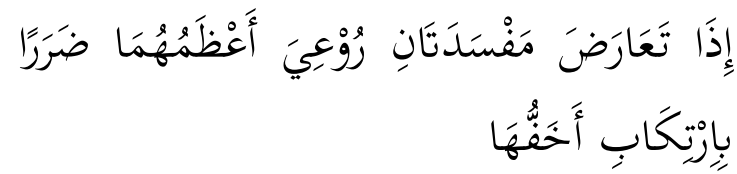

"Jika terdapat dua perkara yang sama-sama membahayakan atau memudharatkan, maka harus dijaga yang lebih besar mudharatnya, dengan mengerjakan yang lebih ringan mudharat atau bahayanya"

Selanjutnya, dikarenakan pernikahan wanita hamil diperbolehkan baik secara Yuridis Normatif dan Hukum Islam, maka akibat hukum dari putusan tersebut adalah diperbolehkannya antara pemohon dan termohon atau calon istri pemohon untuk menikah secara sah. Namun demikian, ada satu hal yang harus diperhatikan yakni meskipun secara hukum islam pernikahannya sah menurut mazhab Syafie, tetapi menikahi wanita hamil dalam hukum islam pada hakikatnya memiliki implikasi terhadap anak yang dilahirkan dari hubungan diluar nikah tersebut, di antaranya:

1. Masalah Nasab Anak

Dalam Islam seorang anak dapat dinasabkan kepada ayahnya apabila memenuhi beberapa persyaratan, diantaranya: (AlZuhaili, 2010) Pertama, dilahirkan dari rahim seorang perempuan akibat perbuatannya dengan suami yang sah. Kedua, bahwa masa kehamilan perempuan tidak kurang dari masa kehamilan pada umumnya yaitu minimal 6 bulan terhitung semenjak pernikahan.

Sehingga dengan demikian, anak yang dilahirkan dari perbuatan zina atau yang dikenal dengan anak luar nikah maka tidak dapat dinasabkan kepada ayahnya melainkan kepada ibunya. Hal ini berdasarkan hadis Nabi saw:

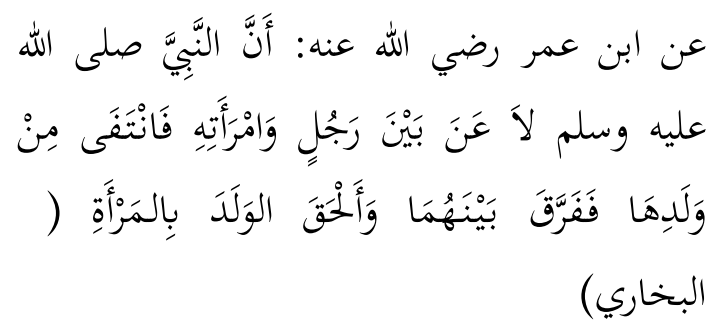

"Dari Ibnu Umar R.A bahwa Nabi saw mengadakan Mula'anah antara seorang laki-laki dengan istrinya, lalu lelaki tersebut mengingkari anaknya tersebut, maka baginda saw memisahkan antara keduanya dan menasabkan anak tersebut kepada Ibunya". (HR. Bukhori)

2. Masalah Wali Nikah

Dikarenakan anak luar nikah tidak dapat dinasabkan kepada ayah biologisnya melainkan kepada ibunya maka jika dia seorang perempuan maka ayahnya tidak dapat menjadi wali nikah. Begitu juga ketika dia seorang laki-laki maka dia juga tidak dapat menikahkan saudara perempuannya. Dan ketika tidak ada wali nasab maka yang bertindak sebagai wali bagi mereka adalah Qadhi (Hasbi, 2013) Hal ini sebagai mana sabda Nabi saw: 


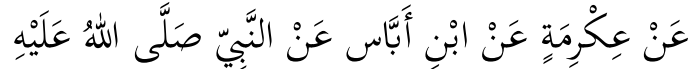

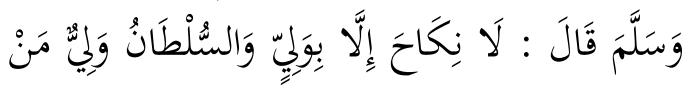

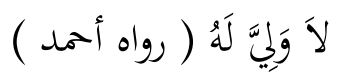

Dari Ikrimah dari Ibnu Abbas dari Baginda saw bersabda: Tidak sah suatu pernikahan kecuali dengan wali. Sedangkan Sultan atau Qadhi adalah wali bagi yang tak memiliki wali. ( HR Ahmad)

\section{Masalah Kewarisan}

Tidak adanya hubungan nasab antara anak yang dihasilkan dari hubungan zina dengan ayah biologisnya, maka ini menyebabkan tidak adanya hak warisan anak terhadap harta peninggalan ayahnya ( Mohtarom, 2018). Hal Ini didasarkan pada hadis Nabi saw.

$$
\begin{aligned}
& \text { أَنَّ رَسُوْلَ اللهِهِ صلى الله عليه وسلم قَالَ : أَتْمَّا }
\end{aligned}
$$

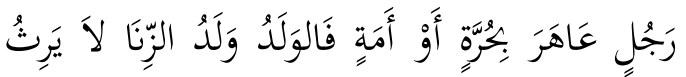

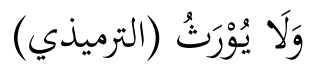

"Sesungguhnya Rosulullah saw bersabda: siapa saja lelaki yang berzina dengan wanita merdeka atau dengan budak wanita, maka anaknya adalah anak hasil zina. Dan anak hasil zina tidak mewarisi dan juga tidak diwarisi". (HR. Tarmizi)

Merujuk hal demikian, anak hasil zina tidak dapat mewarisi harta peninggalan ayahnya begitu juga sebaliknya ia juga tidak bisa mewariskan hartanya kepada ayahnya. Namun pemberikan harta tetap dapat dilakukan baik dalam jalan hibah atau wasiat, karna keduanya tidak mensyaratkan adanya hubungan nasab (Imam Jauhari, 2011)

\section{KESIMPULAN}

Permohonan izin poligami di Pengadilan Agama Bengkalis dengan perkara nomor 0307/Pdt.G/2017/PA. Bkls pada hakikatnya hanya memenuhi syarat kumulatif tetapi tidak memenuhi syarat alternatif. Menurut ketentuan sebagaimana tertuang dalam ketentuan Undang-Undang Perkawinan Nomor 1 Tahun 1974 tentang perkawinan maka permohonan tersebut haruslah ditolak. Akan tetapi Pengadilan Agama Bengkalis dalam kasus ini mengabulkan permohonan tersebut menggunakan asas contra legem dengan pertimbangan jika permohonan pemohon tidak dikabulkan untuk menikah lagi dengan calon istri keduanya tersebut maka mudhorot yang ditimbulkan akan lebih besar bagi calon istri maupun keduanya. Sehingga keputusan ini diberikan oleh majlis hakim dalam rangka untuk melindungi aspek sosiologis dan psikologis calon istri kedua pemohon serta untuk mewujudkan kepastian hukum hubungan keduanya.

Jika ditinjau berdasarkan Hukum Islam, putusan hakim nomor 0307/Pdt.G/2017/PA. Bkls dalam perkara izin poligami pada hakikatnya didasarkan pada pertimbangan- pertimbangan terhadap bahaya serta mudharat yang akan ditimbulkan akibat pemberian atau penolakan izin poligami. dikarenakan kemudaharaan yang timbul jika pengadilan agama tidak mengabulkan permohonan izin pemohon adalah lebih besar dibanding dengan kemudaharatan yang timbul jika pengadilan agama mengabulkan permohonan izin pemohon, oleh karena itu memberi izin kepada Pemohon untuk melakukan pernikahan dengan calon isterinya tersebut 
merupakan solusi yang tepat dalam menyelesaikan permasalahan ini. Hal ini sesuai dengan kaedah fiqhiyah: " $I z a$ Ta'arodho Mafsadatani Ru'iya 'Adhohuma Dhororon Birtikabi Akhofuha" yang artinya jika terdapat dua perkara yang sama-sama membahayakan atau memudharatkan, maka harus dijaga yang lebih besar mudharatnya, dengan mengerjakan yang lebih ringan mudharat atau bahayanya.

Meskipun secara Yuridis Normatif dan Hukum Islam dibolehkannya menikahi wanita hamil di luar nikah dengan syarat bahwa pria yang ingin mengawininya adalah pria yang menghamilinya, namun pernikahan tersebut tetap menyebabkan beberapa implikasi salah satunya adalah status anak yang dilahirkan. Baik menurut Hukum Positif di Indonesia maupun Hukum Islam status anak yang dilahirkan secara keperdataan dihubungkan kepada ibunya dan keluarga ibunya. Sehingga tidak ditemukan adanya kontradiksi antara keduanya.

\section{DAFTAR PUSTAKA}

Abdurrahman. (1992). Kompilasi Hukum Islam di Indonesia. Jakarta: Akademik Pressindo.

Al-Zuhaili, W. (2010). Al Figh Al Islami Wa Adillatuhu. Dar Al Fikr.

Bahasa, T. P. K. P. (2005). Kamus Besar Bahasa Indonesia edisi ketiga. Jakarta.

Chotban, S. (2017). Nilai Keadilan Dalam Syariat Poligami. Al Qadau Peradilan Dan Hukum Keluarga Islam.

Djazuli. (2006). Kaidah- Kaidah Fikih. Jakarta: Prenada media Group.

Hadari Nanawi. (1983). Metode Penelitian
Deskriptif. Yogyakarta.: Gajah Mada Universty Press.

Haikal, A. A. (2006). Ta'addud Az Zaujah Fi Al Islam, damaskus. Dar Al Qolam.

Hasbi, H. M. R. (2013). Nikah MBA (Married by Accident) Dalam Tinjauan Hadis Nabawi. Jurnal AnNida.

Haryono. (2019). Penegakan Hukum Berbasis Nilai Keadilan Substansif. Jurnal Hukum Progresif.

Imam Jauhari. (2011). Hukum Perwalian Anak Zina dan Hak Warisnya. Kanun Jurnal Ilmu Hukum 54.

M. Lia Armadhani. (2016). Poligami Dalam Perspektif Undang-Undang Republik Indonesia Nomor 1 Tahun 1974 dan Syariat Islam. Jurnal Tomalebbi III.

Mohtarom. ( 2018). Kedudukan Anak Hasil Hubungan Zina Menurut Hukum Islam Dan Hukum Positif. Jurnal Al-murabbi.

Pius A. Partanto dan M. Dahlan al-Barry. (1994). Kamus Ilmiah Populer. Surabaya: Arkola.

Saleh, K. W. (1981). Hukum Acara Perdata. Jakarta: Ghalia Indonesia.

sari pusvita. ( 2018). Keperdataan Anak Diluar Nikah Dalam Putusan Mahkamah Konstitusi dan Implikasinya terhadap Harta Warisan. Jurnal Ulul Albab. 